\title{
Corporate Governance: An Islamic Institution Perspective
}

\author{
K. M. Anwarul Islam ${ }^{1}$ \\ Orobah Ali Barghouthi
}

\begin{abstract}
${ }^{1}$ Department of Business Administration, The Millennium University, Dhaka, Bangladesh ${ }^{2}$ Faculty of Business and Economics, Department of Banking \& Finance, Alquds University, Abu Dis, Palestine. Correspondence: Faculty of Business and Economics, Department of Banking \& Finance, Alquds University,Abu Dis, Palestine, E-mail: obargothi@hotmail.com
\end{abstract}

\begin{abstract}
This brings the paper into discussion, including its objectives, procedures, on some of the most important elements of corporate governance, including on tools. The resolution of the conflict of interests of the primary/agent in order to promote the interests of all One of the most important priorities is that of stakeholders, as well as the soundness and stability of the financial system. The Board of Directors, Senior Executive, shareholders and the depositors for this objective are the most important structures. The paper outlines the steps that need to be taken to improve the Board and management 's effectiveness and accountability. To encourage shareholders and depositors to play a higher role in protecting their own interests in the performance of their positions. Then, the article describes some of the popular resources available to make the Board and the Executive more efficient and responsible.
\end{abstract}

Keywords: Islamic View, Corporate Governance, Financial Institution.

\section{Introduction}

The term 'corporate governance' has gained prominence only during the last two decades ${ }^{1}$ and all its ramifications have not yet become fully spelled out even though a substantial volume of literature has become available on the subject. It has been defined in different ways depending upon the author's centre of concern. The Organisation for Economic Co-operation and Development (OECD) has defined it as the "set of relationships between a company's management, its board, its shareholders and other stakeholders." ${ }^{2}$ This is a value neutral definition in the normal tradition of Economics and does not indicate the objective of corporate governance, which is bound to be value oriented. However, Mr. Wolfensohn, World Bank President, has gone a step further and indicated the purpose behind corporate governance to be "fairness, transparency and accountability." 3 This definition makes it clear that the objective is to ensure "fairness" to all stakeholders to be attained through greater transparency and accountability. Fairness may also be taken to imply, in the case of shareholders, a 'fair' growth in the value of their equity. Several other definitions of corporate governance are available but it would not be of great benefit to reproduce them here.

Zingales, 1997, P.1.

OECD, April 1999, P.2.

Financial Times, 21 June 1999, cited by the Encyclopaedia of Corporate Governance in the article on "What is Corporate Governance" (www.encycogov.com), 11 July 2001, P.1. 


\section{Data Analysis}

There are a number of players and stakeholders in Islamic financial institutions. This raises the issue of whether it is necessary to safeguard the interests of all stakeholders. The Western academia is divided into two groups in their discussion of this subject. One of these, the Anglo-American model of corporate governance, focuses exclusively on the maximization of shareholder value. According to this model, if the objective of maximizing shareholder value conflicts with the interests of other stakeholders, those other interests should be ignored.1 The Franco-German model, by contrast, places the same amount of emphasis, at least in theory, on protecting the interests of other stakeholders. There is, however, doubt whether corporate governance in the US is in practice as closely aligned with the interest of shareholders as it appears to be in theory and whether the Franco-German model actually protects the interests of non-shareholder constituencies as much as it is claimed.

The fact that deposits in Islamic banks are not treated as a liability on the balance sheet does not mean that they should not have a minimum capital requirement and improved corporate governance as Emphasis on improved corporate governance and having minimum capital requirement go hand in hand with the need for improvements in risk management standards. Sound risk management practices will minimize adverse consequences faced by financial institutions during periods of uncertainty. Robust internal controls to provide qualitative standards are also necessary to complement the quantitative analysis of risk to provide a check and balance in the overall risk management practices.

An effective risk management system is central to supervisory efforts. The risk management system in Islamic institutions need to be able to address the unique characteristics and attributes associated with Islamic financing operations involving financial contracts and instruments which may give rise to other risks besides credit risk. The risk management infrastructure needs to be in place to facilitate the identification, measurement, monitoring and control of all inherent risks present in all the various types of financing so that the specific risks involved may be 'unbundled'. The complexities of the respective risks in the Islamic financial instruments therefore need to be fully explored and quantified to provide for their effective assessment and management.

Institutionalization of ethics is one of the best approaches to promote and implement the Islamic ethical principles as highlighted above in any organization. Basically, the process of institutionalization of ethics requires a formal initiative to guide key stakeholders in the corporation to implement and promote ethics. Such process is very important in order to control the problem of ethical issues in the corporations (Vitell and Hidago, 2006). The existing practice shows that institutionalization of ethics in corporation can be in the form of establishing permanent board-level committee that responsible to set the policy on ethics, issuance of code of ethics, organizing ethics training, reinforcing the employee's organizational commitment, and encouraging an ethically-oriented organizational culture (Sim, 1991) ${ }^{4}$. All of these actions would be able to create awareness about ethics and at the same time to promote the implementation of ethics as part of corporate governance framework.

Any action and effort to institutionalize ethics adheres most to its key players, within the corporate governance structure of the organization. This raises an issue as to the need for specific agent for such purpose. At this point, several key participants of corporate governance either external such as regulatory and supervisory authorities or internal as in the case of BOD, shareholders, managers, employees and Shari'ah board are considered as agents of ethics.

\footnotetext{
${ }^{4}$ The Institutionalization of Organization Ethics. Journal of Business Ethics, 10 (7), 493-506.
} 


\subsection{Key Players in Corporate Governance (CG) of Islamic Financial Institutions (IFIs)}

\section{Significant Problems}

\begin{tabular}{|c|c|c|}
\hline & Significant Problems & $\begin{array}{l}\text { Purposes / } \\
\text { The Obligations in CG }\end{array}$ \\
\hline \multicolumn{3}{|l|}{ Environment } \\
\hline $\begin{array}{l}\text { The economic, financial, and } \\
\text { legal system as a whole }\end{array}$ & $\begin{array}{l}\text { In the legal system, productivity } \\
\text { Contracts enforceability } \\
\text { Statute of Law }\end{array}$ & $\begin{array}{l}\text { Encourage good market and } \\
\text { legal settings that endorse CG }\end{array}$ \\
\hline $\begin{array}{l}\text { The Government (IFIs } \\
\text { Laws and Regulations) }\end{array}$ & $\begin{array}{l}\text { Laws that promote } \\
\text { Islamic financial institutions' } \\
\text { operations }\end{array}$ & $\begin{array}{l}\text { Provide specific rules and laws } \\
\text { that meet the needs of IFIs. }\end{array}$ \\
\hline Accounting System & $\begin{array}{l}\text { Standards for accounting and } \\
\text { audit of } \\
\text { direct and transparent } \\
\text { communication of information }\end{array}$ & $\begin{array}{l}\text { Provide reliable, simple and } \\
\text { straightforward principles of accounting }\end{array}$ \\
\hline
\end{tabular}

\section{Public Institutions}

The Managers

Financial system stability and soundness (eliminating systemic

Provide instructions for FIs Evaluate business

risk) Establish internal controls,

protocols for

risk management, and disclosure

standards

\begin{tabular}{lll}
\hline $\begin{array}{l}\text { Associations } \\
\text { in Banking }\end{array}$ & $\begin{array}{l}\text { Provide limited } \\
\text { CG requirements }\end{array}$ & $\begin{array}{l}\text { Set standards and } \\
\text { practices of sound }\end{array}$ \\
\hline Institutional & $\begin{array}{l}\text { Rights to Shareholders Share } \\
\text { in gain }\end{array}$ & $\begin{array}{l}\text { Electing members } \\
\text { of the board }\end{array}$ \\
\hline The stockholders & $\begin{array}{l}\text { Ensuring a strong leadership team } \\
\text { Oversight in leadership }\end{array}$ & $\begin{array}{l}\text { Set the policy and plan overall Transparency of } \\
\text { management }\end{array}$ \\
\hline Panel of Directors & $\begin{array}{l}\text { Protect the interests of } \\
\text { stakeholders and equity investors }\end{array}$ & \\
\hline Senior staff & $\begin{array}{l}\text { Effectively running } \\
\text { the institution. Proper mix of } \\
\text { risk and return Efficient } \\
\text { stimulus-structure }\end{array}$ & $\begin{array}{l}\text { Implement in a logical and professional } \\
\text { manner the guidelines set by the board }\end{array}$ \\
\hline The & $\begin{array}{l}\text { Quality of } \\
\text { information and quantity }\end{array}$ & $\begin{array}{l}\text { Ensure that the organisation implements } \\
\text { the guidelines supervisory board (Compliance) }\end{array}$ \\
& $\begin{array}{l}\text { Transparency with } \\
\text { respect to knowledge }\end{array}$ & \\
\hline Employees & Competency and & Meet the objectives set by the organization \\
& work ethics & Reduce hazards to activities \\
& Appropriate & \\
incentive-structure & \\
\hline
\end{tabular}




\begin{tabular}{|c|c|c|}
\hline $\begin{array}{l}\text { Boards } \\
\text { from Sharī'ah }\end{array}$ & $\begin{array}{l}\text { Set rules and values associated } \\
\text { with Sharī'ah }\end{array}$ & $\begin{array}{l}\text { Supervising consistency } \\
\text { with its decision }\end{array}$ \\
\hline \multicolumn{3}{|l|}{ Others } \\
\hline \multirow[t]{3}{*}{ Depositors } & Better service: & Responsibly \\
\hline & good service & behaving \\
\hline & The Returns Comparable & Track the standard \\
\hline \multirow[t]{2}{*}{ External Auditors } & Data quality and quantity & Assess the specificity of the \\
\hline & Informational accountability & quality and quantity of information \\
\hline \multirow[t]{2}{*}{ Sharī'ah Audit } & The binding & Ensure conformity to the \\
\hline & to the Sharī'ahah & verdicts of the Sharī'ah Board. \\
\hline
\end{tabular}

\section{Conclusion}

Islamic banks have made commendable progress over the last two to three decades. They are, nevertheless, relatively very small in terms of their assets and capital, and have not been able to create for themselves a large enough niches in the fields of domestic as well as international finance. It is, therefore, necessary to take all measures that would help promote their expansion.

\section{References}

Al-Ghazali, Abu Hamid Muhammad. (1937). Al-Mustashfa. Vol.1. Cairo: Al- Maktabah Al-Tijariyyah Al-Kubra.

Al-Nawawi, Yahya ibn Sharaf. (2001). Text, Translation and Notes: Imam Nawawi's Collection of Forty Hadith. Kuala Lumpur: Islamic Book Trust.

Arjoon, Surendra. (2005). Corporate Governance: An Ethical Perspective. Journal of Business Ethics, 61 (4), 343-352.

Becht, M and Barca, F. (2001). The Control of Corporate Europe. Oxford: Oxford University Press.

Beekun, Rafeek. I. and Badawi, Jamal. A. (2005). Balancing Ethical Responsibility

Among Multiple Organizational Stakeholder. Journal of Business Ethics, 60, 131- 135.

Beekun, Rafik, I. (1996). Islamic Business Ethics. Herndon, Virginia: IIIT.

Caldwell, C. and Karri, R. (2005). Organizational Governance and Ethical System:A Covenantal Approach to Building Trust. Journal of Business Ethics, 58, 249-255.

Drennan, L. (2004). Ethics, Governance and Risk Management: Lesson From Mirror Group Newsarticles and Barings. Journal of Business Ethics, 52 (3), 257-266. El-Gamal, M. (2006). Islamic Finance, Law, Economic and Practice. New York:Cambridge University Press.

IFSB. (2006a). Guiding Principles on Corporate Governance for Institutions Offering

Only Islamic Financial Services (Excluding Islamic Insurance (Takaful) Institutions and Islamic Mutual Funds. Kuala Lumpur: IFSB.

\section{Copyrights}

Copyright for this article is retained by the author(s), with first publication rights granted to the journal.

This is an open-access article distributed under the terms and conditions of the Creative Commons Attribution license (http://creativecommons.org/licenses/by/4.0/). 